\title{
Energy Input in the Production of Cassava
}

\author{
A. Isaac Bamgboye ${ }^{1} \&$ Babajide S. Kosemani ${ }^{1}$ \\ ${ }^{1}$ Department of Agricultural and Environmental Engineering, University of Ibadan, Ibadan, Oyo State, Nigeria \\ Correspondence: A. Isaac Bamgboye Department of Agricultural and Environmental Engineering, University of \\ Ibadan, Ibadan, Oyo State, Nigeria. Tel: 234-803-719-0626. E-mail: isaacbam22@yahoo.com
}

\author{
Received: November 26, 2012 Accepted: December 18, 2012 Online Published: March 14, 2015 \\ doi:10.5539/eer.v5n1p42 \\ URL: http://dx.doi.org/10.5539/eer.v5n1p42
}

\begin{abstract}
Energy is one of the largest components of the production cost in Agricultural activities. The efficiency of its use will often be compromised in favour of other equally important factors. Data were collected in 10 cassava farms by using face to face questionnaire method to determine the energy input in cassava production. Mathematical expressions were used to evaluate the energy requirement for each of the defined unit operations. Energy requirement in land preparation, planting, crop maintenance (fertilization and weed control) and harvesting were determined. It was observed that $78.67 \%$ of the total energy input used in cassava production was indirect, while $21.33 \%$ was direct. The average energy input in the production of cassava was $8571.26 \mathrm{MJ} / \mathrm{ha}$, while $9960.00 \mathrm{~kg}$ was the average yield obtainable per hectare. Energy input in fertilizer was the highest with $64.0 \%$ of the total energy input; followed by diesel fuel with $19.50 \%$. The net energy and energy productivity value were estimated to be $46,655.77 \mathrm{MJ} / \mathrm{ha}$ and $1.18 \mathrm{MJ} / \mathrm{kg}$ respectively. The ratio of energy output to energy input was 7.1.
\end{abstract}

Keywords: Energy, cassava, renewable fuel, energy ratio, energy productivity

\section{Introduction}

Agriculture is both a producer and consumer of energy. It uses large quantities of locally available noncommercial energy, such as seed, manure and animate energy, as well as commercial energies, directly and indirectly, in the form of diesel, electricity, fertilizer, plant protection, chemical, irrigation water, machinery etc. Efficient use of these energies helps to achieve increased production, productivity and contributes to the profitability and competitiveness of agricultural sustainability in rural living (Singh et al., 2002).

Energy inputs of different forms in agricultural production in almost every country are on the high levels. The reduction of these inputs by using agricultural products and residues as renewable energy sources is and will remain an important issue in future. It is closely related to the environmental problems arising from agricultural production on large surfaces. Therefore, the rational and efficient use of energy is essential for sustainable development. Chamsing, et al., 2006 in their work on some crops stated that for irrigated rice, rainfed rice, maize, wet-season soybean and cassava, energy input varied between 1.79-18.49, 10.09-13.11, 9.79-12.79, 5.21-10.03 and $4.95-9.13 \mathrm{GJ} / \mathrm{ha}$ respectively. They also observed that about $62 \%$ and $38 \%$ of energy inputs in farm operations was from indirect and direct energy inputs respectively. Energy from fertilizer contributed the highest followed by energy from seed, pesticide and herbicide.

Average energy ratio of selected crop production of Thailand was 5.20. This ratio is higher than the ratio of Turkish (1.18) in crop year 2000 (Ozkan et al., 2004) but lower that the ratio of Bangladesh (8.11) in crop year 2000/01 (Alam et al., 2005). Energy ratio for rice, maize and sugarcane production were depended on area and were nearly of the same range as India which were 2.15-12.75 for rice, 4.83-17.02 for maize and 5.82-6.67 for sugarcane production (Singh et al., 1997).

Both direct energy use for crop management and indirect energy use for fertilizers, pesticides and machinery production have contributed to the major increases in food production seen since the 1960s (Woods, 2010). However, the relationship between energy inputs and yields is not linear. Low-energy inputs can lead to lower yields and perversely to higher energy demands per tonne of harvested product. At the other extreme, increasing energy inputs can lead to ever-smaller yield gains.

Cassava (Maninot esculenta) is a perennial woody shrub with up to $32 \%$ (fresh) starch content which is cultivated extensively as a food crop in Africa, is the third largest source of carbohydrate in food for human consumption in the world. Cassava roots play an important role in the African diet and they are processed, using 
simple traditional methods, into products such as Gari, Fufu and Lafun flour. It is estimated that about ten million tonnes of cassava is processed for Gari annually in Nigeria alone. Because of recent characterization of cassava starch properties, market demand for cassava for the production of starch-based products has increased rapidly. This has led to an increase in the cassava growing area, which has reached about 500,000 ha in the past two years. Cassava production system is also changing from being a small-scale subsistence crop to a large-scale commercial crop. This paper determines the energy requirement in the production of cassava in each of the stages of production. This involves land preparation, planting, crop maintenance (fertilization and weed control) and harvesting.

\section{Materials and Methods}

Ten farms were surveyed to collect data on fuel, natural gas, fertilizer, pesticides and chemicals used on the farm for cassava production. The areas of study covered Oyo, Ogun, Osun and Kwara States of Nigeria. Four farms were surveyed in Oyo States, while two farms were surveyed in Ogun, Osun, and Kwara states respectively. The data for energy input resources in all the selected farms during cassava production from land preparation to transportation to the market or house was collected using structural questionnaire and oral interviews. The information obtained was extracted personally from the available documents in the surveyed areas. The input energy was divided into direct and indirect energy. The direct energy consists of diesel, human power and electricity, while the indirect energy contains seeds, fertilizers, farmyard manure, chemicals and machinery.

\section{Processing Technology and Method of Energy Evaluation of Cassava Production}

The type and magnitude of the energy consumed is a function of the process and the technology employed. In order to quantify the energy demands of each unit operation, quantitative data on operating conditions was required for each unit operation. Table 1 summarizes the production technologies under study of the cassava production.

Table 1. Measured Parameters for Evaluating Energy Input in Cassava Production

\begin{tabular}{|c|c|c|}
\hline $\mathbf{S} / \mathbf{N}$ & Operation & Required Parameter \\
\hline 1 & d preparing & $\begin{array}{l}\text { e taken for preparing the land, } \mathrm{h} \\
\text { Number of person involved fuel consumed, } 1 \text { Calorific value of fuel used, } \mathrm{J} / \mathrm{l}\end{array}$ \\
\hline 2 & Stem harvesting & Time taken for preparing the stem, $\mathrm{h}$ \\
\hline 3 & Planting & $\begin{array}{l}\text { Number of person involved. } \\
\text { Time taken to plant the stem, h }\end{array}$ \\
\hline 4 & Herbicide application & Number of person involved. Time taken to apply the herbicide, $h$ \\
\hline 5 & Fertilizer application & $\begin{array}{l}\text { Number of person involved. } \\
\text { Time taken to apply the fertilizer, } \mathrm{h}\end{array}$ \\
\hline 6 & Inter - row Weeding & $\begin{array}{l}\text { Number of person involved. } \\
\text { Time taken for the weeding, } \mathrm{h}\end{array}$ \\
\hline 7 & Harvesting & Number of person involved. Time taken for the harvesting, $h$ \\
\hline 8 & Transportation & Number of person involved. Time taken for the harvesting, $\mathrm{h}$ \\
\hline
\end{tabular}

The types and magnitude of the parameters required for the energy evaluation of each unit operation are presented in Table 2. Jekayinfa and Bamgboye $(2005,2006)$ used similar procedure in the energy audits of palmkernel oil mills and cashew-nut mills in Nigeria.

Table 2. Production Techniques at Each Stages of Production of the Cassava

\begin{tabular}{lll}
\hline S/N & Operation & Equipment and Principle Adopted \\
\hline 1 & and preparing & Mechanized. Tractor 4W, \\
& & Disc plow \\
& & Disc harrow \\
& & Ridger \\
2 & n harvesting and Gathering & Manual with the use of Cutlass \\
3 & iting & 1ual with the use of cutlass.
\end{tabular}


4

5

$6 \quad$ Inter - row Weeding

7 Complete Harvesting

De-stumping axe or machete

Transportation
Manual knapsack sprayer. Boom sprayer-hydraulic

Manual

Manual with the use of cutlass.

De-stumping Manual

Use of truck

Transportation to factory, Tractor 4W - Trailer

The energy evaluation methods for each unit operation are as follows.

\section{Land Preparation}

Initial land clearing of field was done using tractor coupled with a disc plow for primary tillage, while secondary tillage was done using a disk harrow or rotary tiller. The time and fuel consumed by the tractor per hectare during each stage was obtained and used to compute the energy. The energy consumed for land clearing was obtained from the expression:

$$
E_{1 \mathrm{D}}=47.8 \mathrm{D}+3.6(0.075 \mathrm{NTa}) \quad \mathrm{MJ}
$$

Where

$D=$ Amount of diesel consumed per unit operation, $\mathrm{L}$.

$0.075=$ Energy input of an average adult male, $\mathrm{MJ} / \mathrm{h}$.

$T a=$ Useful time spent by a male worker per unit operation,

$N$ is the number of persons involved in an operation

\section{Stem harvesting and gathering}

The amount of bundle required for planting one hectare, the time and the number of people required was obtained from the farmer and was used in the computation of the energy. The energy consumed was obtained from the expression:

$$
E_{\mathrm{bhx}}=3.6(0.075 \mathrm{NTa}) \quad \mathrm{MJ}
$$

\section{Planting}

The amount of time required for planting and the number of people that performed the operation was obtained from the survey and used in the computation of the energy. The energy consumed was obtained from the expressing:

$$
E_{\mathrm{v}}=3.6(0.075 \mathrm{NTa}) \quad \mathrm{MJ}
$$

\section{Pesticide Application}

Pre emergence herbicide spraying was done using a tractor-mounted boom sprayer immediately after the planting operation in some farms. While both pre emergence herbicide spraying and post emergence herbicide spraying was done manually in most of the farms with knapsack sprayer in the farm surveyed. The amount of fuel used, time consumed, number of people involved in the operation, and amount of the pesticide and herbicide used was obtained through the questionnaire during the survey. The energy consumed was obtained from the expression:

When the operation is carried out manually

$$
S_{\text {bua }}=3.0(0.075 \mathrm{NTH}) \quad \mathrm{MJ}
$$

Pesticide energy input (MJ/ha)

Total pesticide input $(\mathrm{MJ} / \mathrm{ha})=P_{28 s} \cdot P_{\text {Rov }}$

$P_{z s s}=$ Applied rate (kg or lit/ha) of pesticide $\mathrm{l}^{\text {th }}$ for applied time

$P_{E g}=$ Energy equivalent $\mathrm{MJ} / \mathrm{kg}$ or litres of pesticide

When tractor-mounted boom sprayer is used

$$
E_{\mathrm{hoa}}=47.8 D+3.6(0.075 N T a) \quad \mathrm{MJ}
$$




\section{Fertilizer Application}

This is done manually in all farms considered. The time required by the farmers to apply the fertilizer, the number of people that applied it, and quantity of fertilizer used per hectare was obtained and the energy input obtained with the following expression:

$$
E_{\mathrm{fa}}=3.6(0.075 \mathrm{NT} T \mathrm{~T}) \quad \mathrm{MJ}
$$

To calculate the labour input

While

Total fertilizer input (MJ/ha)

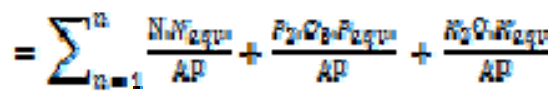

$\alpha_{\text {eov }}=$ Energy equivalent value of $\mathrm{N}=78.1 \mathrm{MJ} / \mathrm{kg}$

$P_{\varepsilon g y}=$ Energy equivalent value of $P_{2} O_{5}=17.4 \mathrm{MJ} / \mathrm{kg}$

$K_{e G v}=$ Energy equivalent value of $K_{2} O=13.7 \mathrm{MJ} / \mathrm{kg}$

$\mathrm{N}=$ Compound fertilizer rate applied $\times$ percentage of $\mathrm{N}$ ingredient $(\mathrm{kg})$

$\mathrm{P}_{2} \mathrm{O}_{5}=$ Compound fertilizer rate applied $\times$ percentage of $\mathrm{P}_{2} \mathrm{O}_{5}$ ingredient $(\mathrm{kg})$

$\mathrm{K}_{2} \mathrm{O}=$ Compound fertilizer rate applied $\times$ percentage of $\mathrm{K}_{2} \mathrm{O}$ ingredient $(\mathrm{kg})$

$\mathrm{n}=$ Compound fertilizer for applied time $\mathrm{l}^{\text {th }}$

\section{Weed control}

Pre-emergence herbicide spraying was done immediately after planting to control the weeds and a contact herbicide was also sprayed in between planting rows to control the weeds after planting in some farms. Some farmers weed their farms by cutting the weed with cutlass and hoe. For herbicide application, the energy input was obtained by measuring the amount of herbicide used and the time it took to apply the herbicide. Energy input was obtained by determining the time required and the numbers of people required for cutting using cutlass and hoe. The follow expressions were used to obtain the energy input.

When herbicide spraying was used:

$$
E_{\mathrm{WG}}=H_{\mathrm{Ser}} \cdot H_{\mathrm{eav}}+3.6(\mathrm{~g} 0.075 \mathrm{ATa} \mathrm{T}) \quad \mathrm{MJ}
$$

Where

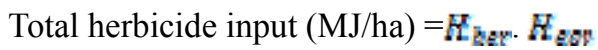

$E_{\text {Eer }}=$ Applied rate (kg or lit/ha) of herbicide $1^{\text {th }}$ for applied time

$R_{\text {eqv }}=$ Energy equivalent $\mathrm{MJ} / \mathrm{kg}$ or litres of herbicide

When weed is done by cutting:

$$
E_{\mathrm{wr}}=3.6(0.075 \mathrm{ET} \mathrm{Taj} \quad \mathrm{MJ}
$$

\section{Biological energy input}

The stem introduced into the soil was considered in the energy computation. The amount of stem (bundle), the amount of a stem stalk in a bundle and the weight of the stem was obtained. Biological energy input was obtained from the expression:

$$
E_{\mathrm{bi}}=\text { Amount of stem applied }(\mathrm{kg} / \mathrm{ha}) \times \text { Energy equivalent of stem }(\mathrm{MJ} / \mathrm{kg})
$$

Where

Energy equivalent of cassava stem $=5.6 \mathrm{MJ}$

Weight of each stalk input $=0.075 \mathrm{~kg}$.

No of stalk in a bundle $=30$ 


\section{Complete Harvesting}

Harvesting was done manually in all the farms. The time taken by the farmer to harvest the cassava root, the number of people involved, and the yields were obtained from the farms. Energy input in this operation was obtained from the expression.

$$
\begin{aligned}
& E_{s w}=3.6(q 0.075 \mathrm{NV} T a) \quad \text { MJ }
\end{aligned}
$$

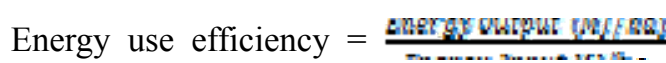

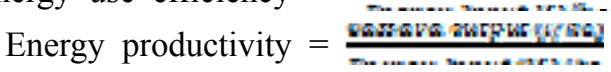

$$
\begin{aligned}
& \text { Net energy = Energy autput (OF) fha) - Energy Input (off kha) } \\
& \text { The energy output }=\text { yfol } \times \text { mergy autvalent }
\end{aligned}
$$

Table 3. Energy Equivalent of Inputs and Outputs in Agricultural Production

\begin{tabular}{lll}
\hline Input (unit) & Energy equivalent (MJ) & References \\
\hline Chemicals $(\mathrm{kg})$ & 120 & Singh 2002 \\
Human labour (h) & 1.96 & Singh, 2002 \\
Machinery $(\mathrm{kg})$ & 62.71 & Singh, 2002 \\
Nitrogen $(\mathrm{kg})$ & 78.1 & Demerirean et al., 2006 \\
Phosphorus $(\mathrm{kg})$ & 17.4 & Demerirean et al., 2006 \\
Potassium $(\mathrm{kg})$ & 13.7 & Demerirean et al., 2006 \\
Cassava $(\mathrm{kg})$ & 5.6 & Demerirean et al., 2006 \\
Diesel fuel (L) & 56.3 & Singh, 2002 \\
\hline
\end{tabular}

\section{Results and Discussion}

\subsection{Result and Discussion}

Energy input in the production of cassava varied from $7388.6-10888.66 \mathrm{MJ} / \mathrm{ha}$ as shown in Table 4. This is relatively higher than $4950-9130 \mathrm{MJ} /$ ha obtained from cassava in Thailand (Chamsing et al., 2006). From the table, energy varied from one farm to another. The variation is caused majorly by the different amount of biological energy input, chemical energy input and difference in method of equipment acquisitions. Tractor and equipment used in the cassava production in this region were obtained through rental, private and partnership. The distance the tractor has to travel to get to the farm and the fuel used in transporting the tractor down to the farm was accounted for. The fertilizer application to the farm also varies, thus contributed to the variation.

Human labour varied from $90.56-421.5 \mathrm{MJ} / \mathrm{ha}$, which was higher than $56.5 \mathrm{MJ} / \mathrm{ha}$ from machinery, but lower than the input fuel of $239-2485.6 \mathrm{MJ} / \mathrm{ha}$. Farm 2 was observed to have the highest energy input of $10,888.66$ $\mathrm{MJ} / \mathrm{ha}$ with the yield of $12,000 \mathrm{~kg} / \mathrm{ha}$, which happens to be the highest cassava yield in this study. It has been observed that low-energy inputs can lead to lower yields and conversely to higher energy demands per kg of harvested product (Woods, et al., 2010). High energy input was attributed to high amount of fuel used in transporting the tractor to the farm from the research institute and the high yield was due to high amount of fertilizer usage. Farm 10 has the lowest energy input of $6634.95 \mathrm{MJ} / \mathrm{ha}$ with a corresponding yield of $7400 \mathrm{~kg} / \mathrm{ha}$. This is as a result of low energy input in fertilizer which resulted in low yield.

The input and output energy values used in cassava production are illustrated in Table 5. The average total energy input of $8560.03 \mathrm{MJ} / \mathrm{ha}$ was required in the production of cassava. This is similar to what was obtained in Thailand from cassava (Chamsing, et al., 2006).

The pattern of energy use as shown in Fig. 1 are chemical fertilizers $64.00 \%, 19.50 \%$ from diesel oil and machinery, human labour $2.20 \%$ and $6.67 \%$ of biological energy (stem). About $77.5 \%$ of the total energy inputs used in cassava production was indirect (stem, fertilizers, chemicals, machinery) and $22.5 \%$ was direct (human labour, diesel). Mean cassava yield was about $9,960.00 \mathrm{~kg} / \mathrm{ha}$. This is close to the national average yield for cassava in Nigeria which varies from 10,000 kg/ha to $15,000 \mathrm{~kg} / \mathrm{ha}$ (Phillips et al., 2004). 
The net energy and energy productivity value were 46,655.77 MJ/ha and $1.18 \mathrm{~kg} / \mathrm{MJ}$, respectively (Table 5). Energy use efficiency of 7.01 was obtained in this work indicates an intensive use of energy inputs in the cassava production. This was within 6.3 to 9.1 obtained by Chamsing, et al (2006) in Thailand. Higher energy ratio in Thailand is as a result of higher yield of cassava $14300(\mathrm{~kg} / \mathrm{ha})$ as compared to $9960(\mathrm{~kg} / \mathrm{ha})$ obtained from this study.

Table 4. Energy Input and Output in the Production of Cassava (MJ/ ha)

\begin{tabular}{|l|r|r|r|r|r|r|r|r|r|r|}
\hline Item & farm 1 & farm 2 & farm 3 & farm 4 & farm 5 & farm 6 & farm 7 & farm 8 & farm 9 & farm 10 \\
\hline Human Labour & 142.7 & 90.56 & 158.25 & 149.25 & 104.62 & 141 & 330 & 285 & 421.5 & 176.25 \\
\hline Machinery & 56.5 & 56.5 & 56.5 & 56.87 & 56.87 & 56.5 & - & 56.5 & - & 56.5 \\
\hline Fuel & 1957.4 & 2485.6 & 2151 & 2103.2 & 2390 & 1764.6 & 239 & 1912 & 239 & 2045.2 \\
\hline Pesticide and Herbicide & 1200 & 1200 & 1200 & 480 & 600 & 1200 & 480 & 960 & 600 & 600 \\
\hline Nitrogen Fertilizer & 2343 & 4686 & 2343 & 3514.5 & 4686 & 3514.5 & 5857.5 & 3514.5 & 4100 & 857.5 \\
\hline Phosphorus Fertilizer & 522 & 1044 & 522 & 783 & 1044 & 783 & 1305 & 783 & 913.5 & 1305 \\
\hline Potassium Fertilizer & 411 & 822 & 411 & 615 & 822 & 615 & 1027.5 & 615.5 & 512.5 & 1027.5 \\
\hline Biological & & & & & & & & & & \\
Energy(Cassava Stem) & 756 & 504 & 567 & 562.50 & 567 & 693 & 630 & 441 & 754 & 567 \\
\hline Total Energy(MJ/ha) & 7388.6 & 10888.66 & 7408.75 & 8264.32 & 10270.49 & 8767 & 9869 & 8567.5 & 7540.5 & 6634.95 \\
\hline Yield (kg/ha) & 10000 & 12000 & 11300 & 9500 & 11200 & 8500 & 11500 & 9200 & 9000 & 7400 \\
\hline Energy Output(MJ/ha) & 56000 & 67200 & 63280 & 53200 & 62720 & 47600 & 64400 & 51520 & 50400 & 41440 \\
\hline
\end{tabular}

Table 5. Energy output - input ratio and energy forms in cassava production

\begin{tabular}{|l|c|r|}
\hline Items & Unit & \multicolumn{1}{c|}{ Quantity } \\
\hline Energy ratio & \multicolumn{1}{c|}{} & 7.01 \\
\hline- & & \\
\hline Energy productivity & $\mathrm{kg} / \mathrm{MJ}$ & 1.18 \\
\hline- & & \\
\hline Net energy & $\mathrm{MJ} / \mathrm{kg}$ & $46,655.77$ \\
\hline Direct energy & $\mathrm{MJ} / \mathrm{kg}$ & $1,928.61$ \\
\hline \multicolumn{1}{|c|}{22.5} & & \\
\hline Indirect energy & $\mathrm{MJ} / \mathrm{kg}$ & $6,642.75$ \\
\hline & & \\
\hline Total energy input & $\mathrm{MJ} / \mathrm{kg}$ & $8,571.26$ \\
\hline- & & \\
\hline Total energy output & $\mathrm{MJ} / \mathrm{kg}$ & 55,776 \\
\hline- & & \\
\hline
\end{tabular}

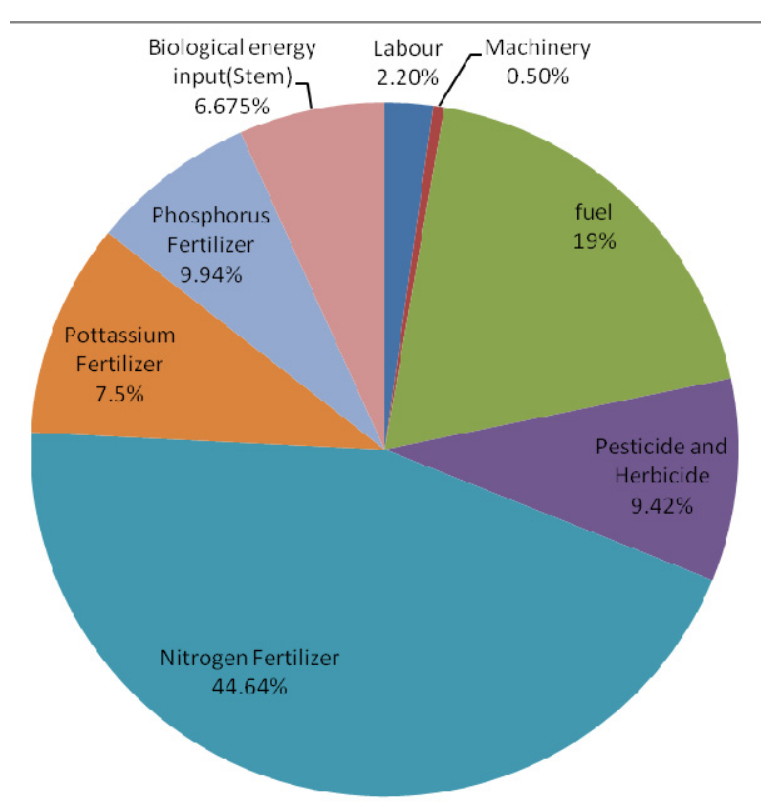

Figure 1. Pie Chat of the Energy Input in the Production of Cassava

\section{Conclusion}

The energy input in each of the cassava production stages was classified into direct and indirect energy. The indirect total energy 
input used in cassava production was $77.5 \%$, while $22.5 \%$ was direct. The average energy input in the production of cassava was $8,571.26 \mathrm{MJ} / \mathrm{ha}$, while the average yields obtainable per hectare was $9,960.00 \mathrm{~kg}$.

\section{References}

Alam, M. S., Alam, M. R., \& Islam, K. K. (2005). Energy flow in agriculture: Bangladesh.American Journal of Environmental Sciences, 1(3), 213-220.

Bamgboye, A. I., \& Jekayinfa, S. O. (2006). Energy Consumption Pattern in Palm Kernel Processing Operations. Agricultural Engineering International: the CIGR Ejournal. Manuscript EE05013, VIII.

Chamsing, A., Salokhe, V., \& Singh, G. (2006). "Energy Consumption Analysis for Selected Crops in Different Regions of Thailand". Agricultural Engineering International: the CIGR Ejournal. Manuscript EE 06013. VIII.

Jekayinfa, S. O., \& Bamgboye, A. I. (2005). Estimating Energy Requirement in Cashew (Anacardium Occidentale L.) Nut Processing operations Energy, 31(8-9), 1305-1320

Ozkan, B., Akcaoz, H., \& fert, C. (2004). Energy input-output analysis in Turkish agriculture. Renewable energy, 29(2004), 39-51

Phillips, T. P., Taylor, D. S., Sanni, L., \& Akoroda, M. O. (2004). A cassava industrial revolution in Nigeria: The potential for a new industrial crop. Retrieved from http://www.fao.org/docrep/007/y5548e/y5548e 00.htm (March, 2011).

Singh, H., Mishra, D., \& Nahar, N. M. (2002). Energy use pattern in production agriculture of typical village in arid zone", India - part-I. Energ Convers Manage, 43, 227-586.

Woods, J., Williams, A., Hughes, J. K., Black, M., \& Murphy, R. (2010). Energy and the food system. Phil. Trans. R. Soc. B365, 2991-3006.

\section{Copyrights}

Copyright for this article is retained by the author(s), with first publication rights granted to the journal.

This is an open-access article distributed under the terms and conditions of the Creative Commons Attribution license (http://creativecommons.org/licenses/by/3.0/). 